\title{
ISSUES OF FORMING THE REVENUE SIDE OF LOCAL BUDGETS IN KAZAKHSTAN AND ABROAD
}

\begin{abstract}
The article is devoted to such important indicators and tax policy as local taxes. The article also reviews the role of local budgets in formulating the overall budget of the republican budget, formulating international fiscal budget. The article also reviews the role of local budgets in formulating the overall budget of the republican budget. In the article, the analysis of the model of interbudgetary relations with the Chinese model, the American model, the German model. The comparative table compares the unitary and federation form of the board. The data of Aktyubinsk region's budget and receipt of the transport tax in the Republic of Kazakhstan were used. The materials are based on current economic development data, current legislation, and also the Address of the President of the Republic of Kazakhstan and other regulatory legal acts.

Purpose of the study: is to determine the role and importance of local taxes, fees in the formation of the revenue side of local budgets in Kazakhstan and abroad, to consider one of the main tasks of the state revenue authorities to implement the revenue side of the budget, to conduct a comparative analysis of the formation of local budgets in Kazakhstan and abroad

Research methods: The methods of scientific research were used in the article: analysis, synthesis, generalization, system analysis, comparative analysis, observation. The following activities were carried out during the research: determination of the role and importance of local taxes, levies in the formation of the revenue side of local budgets in Kazakhstan and abroad, the study of one of the main tasks of the state revenue authorities in the execution of the revenue side of the budget, and the comparative analysis of the formation of local budgets in Kazakhstan and abroad.

Results: The results of the survey show that local budgets in Kazakhstan are mainly provided by tax revenues, namely, through local taxes and fees.
\end{abstract}

KEYWORDS: taxation, local taxes, tax revenues, budget, budget revenues and transfers 


\section{INTRODUCTION}

One of the main tasks of the state revenue bodies is the execution of the revenue side of the budget. State budget unites the republican and local budgets, the consolidated budget includes the republican budget, budgets of the regions, cities of republican significance, the capital and receipts sent to the National Fund of the RK, and the regional budget consists of the regional budget, the budgets of the districts (The law of RK, 2001. About local state management and self-government in the Republic of Kazakhstan, p. 15).

In the message of the President of RK N.Nazarbayev to the people of Kazakhstan "New opportunities for development in the conditions of the fourth industrial revolution" it is said: "Within the framework of fiscal decentralization, it is necessary to solve the issue of transferring corporate income tax from small and medium businesses. Since January 1, 2018 in the cities of regional significance, villages and rural districts with a population of more than 2 thousand people, the legislation provides for the introduction of an independent budget and municipal ownership of local government. Since 2020, these norms will operate in all settlements. 7 types of tax and other non-tax revenues will be transferred to the village budget, as well as 19 areas of expenditure. This allows people to involve in solving issues of local importance" (Nazarbayev, 2018, p. 9).

\section{LOCAL BUDGETS IN THE TAX SYSTEM OF KAZAKHSTAN}

Local budgets are regional budgets, budgets of Almaty and Astana, as well as the budgets of the districts (cities of regional importance) are centralized money funds formed from the corresponding revenues, which are used to finance the tasks and functions of local government bodies, in accordance with the level of public administration and taking into account the implementation of state policy administrative-territorial unit (Baidusenov, 2004, p. 23-32). Local budgets are approved by decisions of respective maslikhats. The types and levels of budgets of Kazakhstan are presented (Figure 1). 
Figure 1.

Types and levels of budgets of Kazakhstan

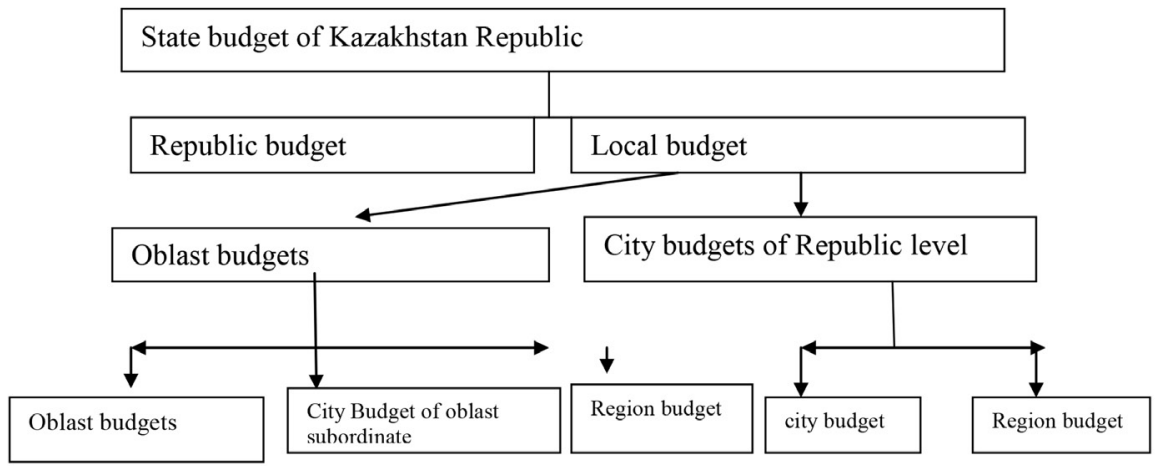

Source: own development

Each region, Almaty and Astana approve their own budget with the decision of the corresponding maslikhat. The level of incomes and costs varies depending on the region (Figure 2).

To equalize the level of budget provision in the regions and ensure equal fiscal opportunities and provide state-guaranteed services in accordance with the areas of expenditure assigned to each level of the budget, general transfers are provided (Rakhmetova, 2016, p. 692-698).

Figure 2.

Incomes and expenditures of local budgets (updated plan for 2017)

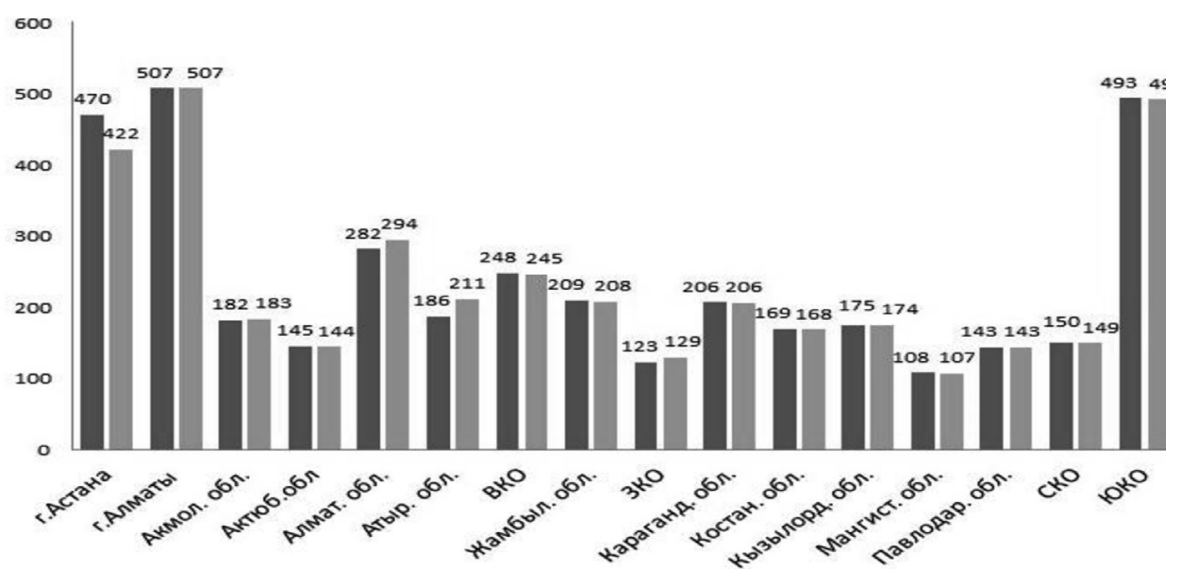

Source: Decisions of the regional maslikhats of the Republic of Kazakhstan for 2017-2019. 
When determining general transfers, tax potential of the region, the number of consumers of public services in the region, the approved standards of public services, and the factors affecting the costs of providing public services, depending on the specifics of a particular region are taken into account (Figure 3).

Figure 3.

Budgetary subventions and withdrawals for 3 years (2015-2017), concerning republican budget, billion tenge

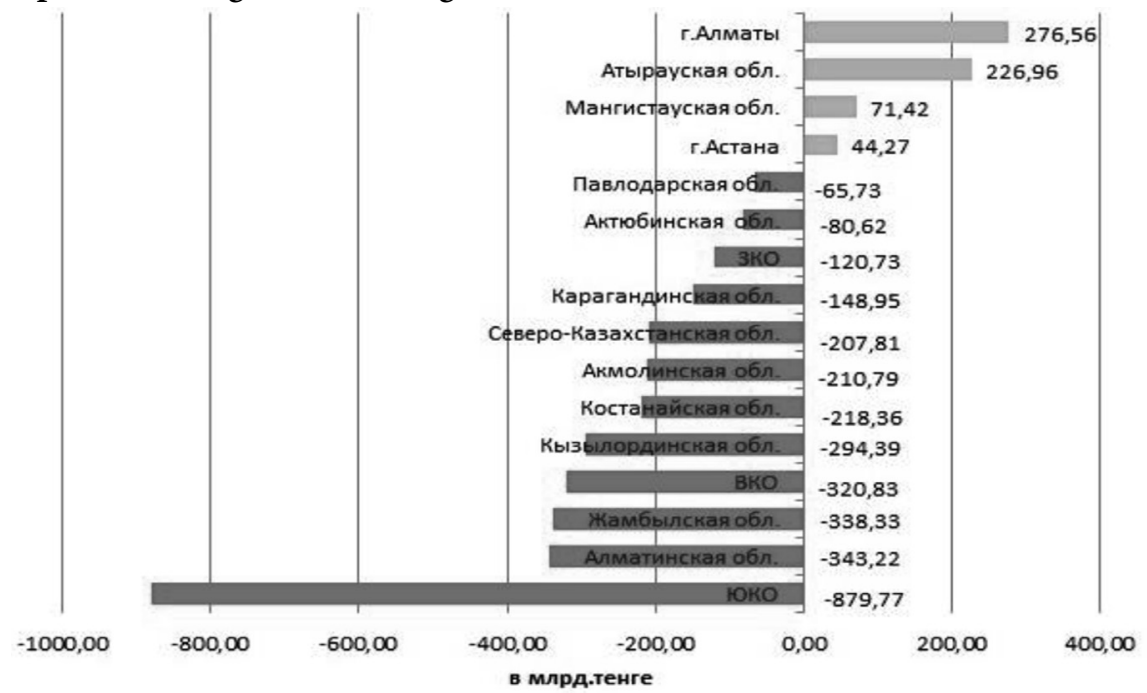

Source: own development

On the basis of the data set out in the graph, it can be concluded that only three budgets ("Atyrau and Mangystau oblasts and the city of Almaty") are "withdrawn" from the republican budget to the remaining 12 regions and to Astana. In turn, each oblast adopts budgetary exemptions and subventions to districts (cities of regional significance) from the budget decision of the maslikhat (http:// aktobe.gov.kz, 2017, p 5-7). It should not be assumed that those from whom the funds are "withdrawn" will not receive anything from the higher budget, for this purpose there are targeted transfers, which, based on their name, are transferred for certain purposes and cannot be used for other purposes. 


\section{ANALYSIS OF THE EXECUTION OF LOCAL BUDGETS IN KAZAKHSTAN FOR 2017}

Analyzing the execution of the budget of the Aktobe region of the RK, one can see the following. As a result of 2017, the consolidated budget of the Aktyubinsk region was fulfilled by $107.3 \%$, with the plan 440.5 billion tenge, 472.6 billion tenge was received. The growth rate compared to the same period last year was $137.4 \%$ or 128.7 billion tenge more (http://aktobe.gov.kz. 2017, p 3).

According to the republican budget, the xecution of the plan amounted to $100.9 \%$. In comparison with the same period last year it is more by 75.7 billion tenge. According to the local budget, execution of the plan amounted to $103.2 \%$, over the plan received 3.1 billion tenge or by 4.4 billion tenge more than in the same period last year (http: //nbsk.kz.2017, p 2).

In order to ensure the implementation of the revenue plan, work was carried out to reduce the shadow turnover and identify additional reserves and provided to the budget revenues in the amount of 47.8 billion tenge, including:

- Based on the results of the inspections, 23, 0 billion tenge were raised to the National Fund.

- According to the results of desk control is 16.2 billion tenge

- Based on the results of tax audits is 0.54 billion tenge

- For customs inspections is 0.093 billion tenge.

- LDC recovered is 0.32 billion tenge

- Damage caused by the completed y / d (1-M) is 7.6 billion tenge (http:// ranking.kz, 2017, p.14).

Arrears in the Aktyubinsk region as of 01.01.2018 amount to KZT 11.5 billion, compared with the beginning of the year $(01.01 .2017)$ there is a decrease of KZT 2, 1 billion or $15.6 \%$.

Transport tax is of special importance in the structure of tax revenues to the local budgets of the RK.

For the year of 2017, the amount of tax on vehicles increased by $11 \%$ to KZT46.9 bn. Let's notice that for 10 years collection of taxes from motorists has grown in 4, 5 times, despite the fact that the number of registered cars has grown only by 50\%, according to ranking (http: // ranking.kz, 2017, p. 15). 
In 2017, the vehicle tax increased by an average of $6 \%$, which would increase tax collection from motorists by another 13\%, to KZT 53 billion at the end of the year (Figure 4).

For 2017, tax revenues increased by $30 \%$ compared to the same period last year and amounted to 17.2 billion tenge. On average, there were 12.2 thousand tenge in one year in 2016 . The bulk of the proceeds or $82 \%$ comes from individuals.

Figure 4.

Collection of taxes on vehicles (billion tenge)

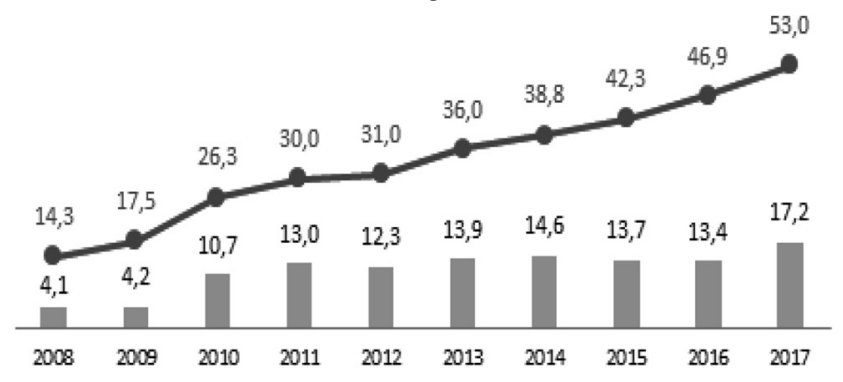

Source: own development

More than half or $64 \%$ of the total tax collection in 2017 was for car enthusiasts with cars from 1500 to $2000 \mathrm{cc}-13.3$ billion tenge and for cars over 4000 cc. $-16,6$ billion tenge (Figure 5).

Figure 5.

Collection of taxes on vehicles depending on the volume of the engine (billion tenge)

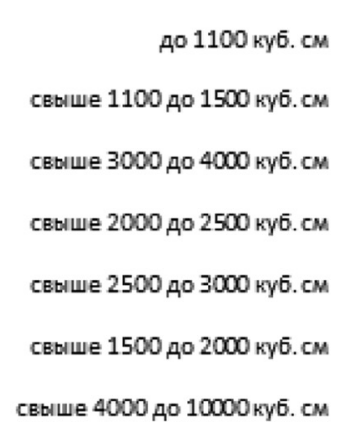

Source: own development

\section{3,3}

16,6 
The largest number of new large engine volume is concentrated in Almaty and Astana, which is the reason for the highest tax charges in the country.

\section{INTERNATIONAL EXPERIENCE IN THE FORMATION OF LOCAL BUDGETS}

International experience shows that existing models of interbudgetary relations can be conditionally divided into 3 main types: the Chinese model; American model; German model. In the US there is a classic budgetary federalism. The federation, states and municipalities have their own "non-overlapping" taxes and even autonomous tax services. There are no deductions from federal taxes to the state budgets. Absolute independence of the states in the process of forming revenue items of budgets is this: you can raise rates, introduce new types of taxes or issue bonds (Zhurikov, 2016, p. 3).

The only condition is that you cannot ask for money from the center. Financial assistance is distributed mainly in the form of targeted subventions, the goals for which are determined based on national priorities. In the United States, there is the highest economic efficiency and social justice. The federal government has a responsibility to finance national defense and state social security systems. The US Constitution only grants its own tax powers to the federal and regional governments, while the municipal authorities receive the rights to establish and collect taxes as a result of their delegation by the state authorities. Interbudgetary alignment in the US is represented by a complex system of budgetary grants allocated to budgets of various levels. At the same time, the dependence of subnational budget budgets on federal transfers is strong enough: in 2000, for example, federal transfer funds averaged $18.9 \%$ of the expenditures of consolidated state budgets. At the same time, the share of financial assistance from regional budgets in the expenditures of local budgets was $43.4 \%$ for the same period. In the United States, both conditional and unconditional financial assistance are provided to lower-level budgets. The basic type of unconditional financial support is the program of interbudgetary income equalization, based on the allocation of transfers calculated according to a legally approved formula that takes into account expenditure needs and fiscal potential (Komekbaeva, 2012, p. 152). 
Currently, federal budget does not provide untargeted financial assistance to lower-level budgets, although unconditional financial support to local budgets from the state budgets is widely used. Targeted financial assistance is provided in the form of grants of two types - block grants and so-called category grants. In the US, there is no legislative norm that determines that the federal budget should not be reduced without a deficit, and the federal government has the right to attract borrowed financial resources to finance the federal budget deficit. In contrast to the federal budget, state legislation in most cases requires the lack of deficit of regional and local budgets for current expenditures, as a result of which state and municipal administrations have the right to raise funds on a long-term basis, with the goal of financing only capital expenditures. Regulations governing the procedure for borrowing are contained in the constitutions and laws of the states and, as a rule, vary greatly, depending on the specific state (Panskov, 2015, p. 319).

The main method of state and municipal borrowing in the United States is issuance of state and municipal bonds, circulating without restrictions. At the same time, the interest income received on these securities is not subject to federal income tax. An important feature of the US budget system is that the federal government is not responsible for securities issued by lower-level authorities. In this situation, investors rely on the ratings of private agencies, which ultimately determine the price of borrowing state and municipal budgets on the open market. This model is interesting from the point of view of studying budget procedures and technologies, adaptation of individual elements is possible, but in general for Kazakhstan it is unsuitable because of differences in the structure of the state apparatus and the absence of many initial conditions, in particular, civil society. The combination of the principles of economic efficiency and social justice is close to the optimal one. Many elements (completion of rates, alignment schemes) can be adapted to Kazakhstan conditions; however, direct copying of the model is also impossible (Lykova, 2015, p. 353).

The German model is based on the ideology of the "cooperative" one. The budgetary system is based on "general" taxes, the proceeds from which are distributed among all its levels. In this case, their partial redistribution is 
realized, i.e. there is a differentiation of the norms of allocations. The purpose of such redistribution is to narrow the gap between donor lands and recipient lands. Direct financial assistance from higher budgets is relatively small, but in practice the practice of numerous and very large federal and joint programs of regional development are developed. Expenditure powers are distributed in accordance with the principles of "classical" fiscal federalism (Ordinskaya, 2015, p. 406).

In the provision of social services, government agencies do not come from minimal social standards, but from the principle of ensuring an equal standard of living for all residents of the country. The powers of the land authorities extend to the regulation of issues of culture, education, law and order, health, and regional economic policy. The municipal authorities are responsible for municipal services, local health care institutions, and sports, construction of housing, roads, and schools. At the same time, the scope of competence of the authorities at different levels does not always coincide with their spending powers. Expenditures in the field of social policy and construction of infrastructure facilities are carried out by budgets of all levels. There is also a tendency to transfer expenditure responsibilities to the lower level of the budget system: currently, about two-thirds of all state capital expenditures are financed from municipal budgets, with most of the authority for their financing transferred to higher-level budgets (Chernik, 2016, p. 364).

The German budgetary system is characterized by a three-level system of interbudgetary equalization. First, a profitable alignment is realized through the receipt of VAT in the budgets of the subjects of the federation. The second type of interbudgetary equalization is the redistribution of budget resources between the land budgets without interference from the federal government. The third type of financial support for the regions is direct federal grants to certain territories.

Thus, the regulation of attracting loans by local governments faces certain difficulties: firstly, due to the lack of a loan capital market for municipal budgets, it is difficult to control the compliance of the borrowing price with market rates, and secondly, it is impossible to prevent loans from local savings banks established by municipal authorities (Polyak, 2015, p. 474). 
The review of budget systems and systems of interbudgetary alignment of countries with federative and unitary state structure allows the following conclusions. The peculiarity of the budget systems of these states is, first of all, in the much greater self-sufficiency of the authorities of the subjects of the federation, i.e. second after the central government level of power in the country, in the field of establishing tax rates and the introduction of new taxes, the distribution of expenditure powers and disposition of funds of their own budgets.

\section{Table 1}

\section{Comparative table of advantages of unitary and federative forms of government}

\begin{tabular}{|c|c|}
\hline Unitary form & Federative form \\
\hline \multirow[t]{2}{*}{$\begin{array}{l}\text { 1. Uniformity. With this system, the same } \\
\text { government programs are used everywhere, } \\
\text { the same policy is being implemented. }\end{array}$} & $\begin{array}{l}\text { 1. Selection. The main advantage of federalism } \\
\text { is that, it offers a combination of external } \\
\text { unity and internal diversity that no other } \\
\text { form of government can provide. }\end{array}$ \\
\hline & $\begin{array}{l}\text { 2. Participation. Citizens have great oppor- } \\
\text { tunities to influence the democratic process } \\
\text { and take advantage of it, when decisions and } \\
\text { those who accept them are nearby and more } \\
\text { accessible. }\end{array}$ \\
\hline $\begin{array}{l}\text { 2. The same opportunity to receive services. } \\
\text { Enterprises and individuals live and work in } \\
\text { a holistic, unified management system and } \\
\text { have the same opportunities to receive the } \\
\text { benefits they provide. }\end{array}$ & $\begin{array}{l}\text { 3. Experiment, innovation and competition. } \\
\text { Independence of subjects of the federation } \\
\text { in solving many issues means that the } \\
\text { authorities of the lowest level have the } \\
\text { opportunity to develop their own approaches } \\
\text { to solving important problems for their } \\
\text { voters. Innovations are not a threat to } \\
\text { national security, as it could have happened if } \\
\text { they were introduced on a national scale }\end{array}$ \\
\hline \multirow{2}{*}{$\begin{array}{l}\text { 3. Common trading space. Trade is free, because } \\
\text { as you move around the country, you do not } \\
\text { need to figure out new rules. }\end{array}$} & $\begin{array}{l}\text { 4. Reporting. When important decisions are } \\
\text { made in the immediate vicinity of voters. }\end{array}$ \\
\hline & $\begin{array}{l}\text { 5. Regional majority. Due to the ability to adjust } \\
\text { services in accordance with the preferences of } \\
\text { the local population, the federative state can } \\
\text { successfully smooth out regional differences } \\
\text { and mediate settlement of emerging disputes. }\end{array}$ \\
\hline
\end{tabular}

Note. It is made on the basis of the source. 
In countries with a federal arrangement, the expenditure obligations of the budgets of the subjects of the Federation are much wider than those of similar levels in unitary states. Unitary states are characterized by uniformity of taxes, payments and budgetary process throughout the country, and in federal states, these parameters may differ from each other in different subjects of the federation, depending on regional legislation. The analysis shows that, theoretically, the lower-level budgets in unitary states are intermediate funds for the distribution of resources of the central government and the accumulation of those resources, which administration at this level seems to be the most effective.

In countries with a federal state structure, the budget of each level is the self-sufficient fund of financial resources that mobilizes and distributes its own financial resources. At the same time budgets of various levels are interconnected by a system of inter-budgetary relations, built in accordance with federal legislation. The above thesis finds confirmation at least in the fact that in unitary states, in contrast to federations, the central government is responsible for the debt of the budgets of the lower levels, and also sets limits on the amount and timing of borrowing (Guseva, 2015, p. 432).

In addition, unitary states are characterized by high (more than $50 \%$ ) share of the central budget in the income of lower-level budgets. The review of budgetary systems has shown that the role and scope of responsibility of municipal authorities and their budgets are approximately the same in states with different arrangements. In almost all cases, municipal authorities have obligations to finance expenditure items exclusively of local significance. In the revenues of these budgets, property taxes and local licensing and registration fees are credited, and the revenue base of the lower-level budgets, as a rule, depends heavily on the means of the higher budgets. At the same time, one cannot say that the principle of state structure determines the distribution of rights and obligations between the levels of the budget system. The right of social justice is ensured, but at the expense of some damage to economic efficiency (Aleksandrov, 2017, p. 317). 


\section{Table 2}

\section{Comparative table of weaknesses of unitary and federative forms of government}

\begin{tabular}{|c|c|}
\hline Unitary form & Federative form \\
\hline \multirow[t]{2}{*}{$\begin{array}{l}\text { 1. Lack of flexibility. The single government } \\
\text { does not have the ability to responsively react } \\
\text { to regional specificities. }\end{array}$} & $\begin{array}{l}\text { 1. Duplication. Rarely, the powers between the } \\
\text { levels of power in the state are divided so } \\
\text { clearly that it is completely possible to avoid } \\
\text { duplication of one and the same activity and } \\
\text { accordingly to obtain unnecessary results. } \\
\text { A unitary state is able to exercise more } \\
\text { stringent control and reduce such a kind of } \\
\text { duplication to a minimum. }\end{array}$ \\
\hline & $\begin{array}{l}\text { 2. Obscurity with responsibility. At the top } \\
\text { level, you might think that the issue is solved } \\
\text { at the bottom, and at the bottom - consider } \\
\text { what they are doing at the top, and as a result, } \\
\text { some problems remain unresolved. }\end{array}$ \\
\hline \multirow{3}{*}{$\begin{array}{l}\text { 2. The clumsyness of a bureaucratic machine. } \\
\text { When the implementation of state programs } \\
\text { on the territory of the entire large country } \\
\text { falls on the shoulders of one governing } \\
\text { body, its administrative structure becomes } \\
\text { too cumbersome to effectively perform its } \\
\text { functions. All this makes the management } \\
\text { apparatus costly, incapable of taking into } \\
\text { account the interests of regions and citizens. }\end{array}$} & $\begin{array}{l}\text { 3. National unity. The commitment of the lower } \\
\text { levels to independence may contradict the } \\
\text { idea of national unity and desire to support } \\
\text { the ongoing state policy. }\end{array}$ \\
\hline & $\begin{array}{l}\text { 4. Interventions in the affairs of the internal } \\
\text { common market. The authorities of the } \\
\text { subjects of the federation, having sufficient } \\
\text { independence, may impede free trade, } \\
\text { border crossing in an effort to protect local } \\
\text { producers. The federal authorities should } \\
\text { have the means to combat this, often an } \\
\text { emerging phenomenon in order to protect } \\
\text { economic markets from encroachment by the } \\
\text { subjects of the federation. }\end{array}$ \\
\hline & $\begin{array}{l}\text { 5. Not the highest level of service society. } \\
\text { Competition between the authorities of the } \\
\text { subjects of the federation can lead to the fact } \\
\text { that budget allocations and the provision of } \\
\text { appropriate services to society will not be } \\
\text { optimal for the state as a whole. }\end{array}$ \\
\hline
\end{tabular}

Note. It is made on the basis of the source.

It is clear that Kazakhstan, trying to become a financial center of independent significance, will not copy any of the presented models. The whole set of possible solutions is reduced to a certain combination of 
certain elements of different models. The result may be either a non-viable compilation, or a fundamentally new model of inter-budgetary relations (Dadashev, 2013, p. 240).

Of course, in order to build a model of interbudgetary relations, it is necessary to take a series of successive steps: to allocate responsibility for spending, to consolidate revenues between the levels of budgets while ensuring leveling of the development level of the territories.

Thus, only those functions can be transferred to the local level, the implementation of which requires directly exercising by the local state authority's power authorities in determining the methods, forms and sizes of social payments, etc.

The experience of countries with developed market relations shows that the costs associated with social stabilization (payment of various social benefits), and the costs that affect the distribution of income of the population (for social protection), are usually functions of the central government. The costs of those types of services, for which special importance is the effective investment of resources, is best transferred to different levels of power, depending on the expansion of the scope of application (distribution).

Ideally, the financing of social services that bring collective benefit is realized from the budgets of various levels in proportion to the real volume of financial authority of local and central levels of government (Kibanova, 2012, p. 488).

\section{Conclusions}

In practice, a strict division of the volume of financing between local and central levels of power depends on the scale transferred to the places of functions and powers and their state significance, as well as the size and stability of the tax base. In this case, it is necessary to take into account the unevenness of the economic development of various territorial units. Local budgets for financing expenditures for social needs of the population should not be dependent on revenues coming from the budgets of higher levels (Pogorelov, 2013, p. 208).

Thus, local budgets in Kazakhstan are mainly provided at the expense of tax revenues, namely, through local taxes and fees. Due to these funds, 
socially significant programs are being financed for the regions, such as the development and stimulation of entrepreneurship, the content of the educational sphere, the financing of health care, the provision of social assistance, and so on.

\section{References}

Aleksandrov, I.M. (2017). Taxes and taxation / IM. Alexandrov. Moscow: Dashkov and K., p. 317.

Baidusenov, A.D. (2004). Tax system of Kazakhstan. Almaty: Finance of Kazakhstan, p. 23-32

Chernik, D.G. (2016). Theory and history of taxation: a textbook for the academic bachelor / D.G. Chernik, Yu. D. Shmelev; Ed. G. . Cernica. Moscow: Publishing House Yurayt, Series: Bachelor. Academic course, p. 364.

Dadashev, A.Z. (2013). Taxes and taxation in the Russian Federation: Textbook / A.3. Dadashev. M.: University textbook, SIC INFRA-M., p. 240.

http:// aktobe.gov.kz (2017). Decisions of the regional maslikhats of the Republic of Kazakhstan for 2017-2019, p 5-7 (access 11.08.2018).

http://aktobe.gov.kz (2017). Execution of the budget of Aktobe region of Republic of Kazakhstan for 2017, p. 3 (access 11.08.2018).

http: //nbsk.kz (2017). National budget network of Kazakhstan. The local budget of the Republic of Kazakhstan is 2017, p. 2 (access 11.08.2018).

http://ranking.kz (2017). Calculations based on the data of KGD MF RK, p. 14 (access 11.08.2018).

http: // ranking.kz (2017). Calculations based on the data of the COP MNE RK, p. 15 (access 11.08.2018).

Guseva, T.A. (2015). Tax planning in business. Legal regulation / T.A. Gusev. Moscow: Volters Kluver, p. 432.

Kibanova, A.Y. (2012). Taxes and taxation / A.Y. Kibanova. Moscow: KnoRus, p. 488.

Komekbaeva, L.S. (2012). Baisbai E.M. Foreign experience in the formation of interbudgetary relations. Vestnik KarSU. Karaganda, p. 152.

Lykova, L.N. (2015). Taxes and taxation: a textbook and a practical work for academic bachelor's degree / L.N. Lykova. Moscow: Yurayt Publishing House, Series: Bachelor. Academic course, p. 353. 
Nazarbayev, N. (2012). Message from the President of Kazakhstan, the leader of the nation, N.Nazarbayev to the people of Kazakhstan. Strategy "Kazakhstan 2050". "New political course of the held state" of December 14, 12-4.

Nazarbayev, N. (2018). Message of the President of the Republic of Kazakhstan to the people of Kazakhstan "New opportunities for development in the conditions of the fourth industrial revolution". Astana: Akorda. p. 9.

Ordinskaya, E.V. (2015). Organization and methodology for conducting tax audits: a training manual and a workshop for STR / EV Ordynskaya; Ed. L. S. Kirinoy. Moscow: Yurayt Publishing House, Series: Professional education, p. 406.

Panskov, V.G. (2015). Taxes and taxation. Workshop: a manual for universities / V.G. Panskov, T.A. Levochkina. Moscow: Yurayt Publishing House, Series: Bachelor. Academic course, p. 319.

Pogorelov, M.Y. (2013). Taxes and taxation: Theory and practice: Textbook / M.Ya. Pogorelov. Moscow: IC RIOR, SIC INFRA-M, p. 208.

Polyak, G.B. (2015). Taxes and taxation: a textbook and a workshop for SPE / ed. G. B. Polyak, 2 nd ed., Pererab. and additional. Moscow: Yurayt Publishing House, Series: Professional education, p. 474.

Rakhmetova, A.B. (2016). Local taxes in the formation of profitable part of the budget of Akmola region // Astana: Young Scientist. No. 9, p. 692-698.

The law of RK (2001) "About local state management and self-government in the Republic of Kazakhstan - № 148. with the changes made of 09.02.2009 N 126, p. 15. Zhurikov, K.K. (2016). Foreign experience and practice of organization and functioning of local budgets // Banks of Kazakhstan, p. 3. 
